Article

\title{
Returns to Foreign and Host Country Qualifications: Evidence from the US on the Labour Market Placement of Migrants and the Second Generation
}

\author{
Sergio Lo lacono ${ }^{1, *}$ and Neli Demireva ${ }^{2}$ \\ ${ }^{1}$ Department of Political and Social Sciences, European University Institute, 50014 Firenze, Italy; \\ E-Mail: Sergio.Lolacono@EUI.eu \\ 2 Department of Sociology, University of Essex, Colchester, CO4 3SQ, UK; E-Mail: nvdem@essex.ac.uk \\ * Corresponding author
}

Submitted: 30 March 2018 | Accepted: 4 May 2018 | Published: 30 July 2018

\begin{abstract}
The integration of migrants in the US economic system is a central concern of policy-makers and scholars. A faster and smoother assimilation of valuable human capital would indeed benefit the labour market, increasing its efficiency. To investigate the integration of minorities and migrants in the US labour market, we employ data from the Current Population Survey from June 2016 (the primary source of labour force statistics in the US). We focus on the following ethnic groups: White, Black, Asian, and Other (a combination of Native Americans, Pacific and Mixed). For each ethnicity we consider if respondents are US born, 1st- or 2nd-generation of immigrant descent. Among 1st-generation migrants, we further differentiate between recent (in the country for 10 years or less) and long (in the country for more than 10 years) arrivals, as they are likely to have different levels of social capital and knowledge of the job market. We focus on three very relevant labour market outcomes: being employed, being employed in a public sector job and working in a professional or managerial position. Our results indicate better placement of individuals with tertiary degrees, an effect particularly important among women. Minorities in the public sector have made some important gains in terms of occupational attainment parity with the white majority.
\end{abstract}

\section{Keywords}

ethnic; foreign; host country; labour market attainment; minorities; private sector; public sector; qualifications

Issue

This article is part of the issue "The Race for Highly-Skilled Workers", edited by Neli Demireva (University of Essex, UK) and Ivana Fellini (University of Milano Bicocca, Italy).

(C) 2018 by the authors; licensee Cogitatio (Lisbon, Portugal). This article is licensed under a Creative Commons Attribution 4.0 International License (CC BY).

\section{Introduction}

This thematic issue focuses on the utilization of the human capital of migrants and different minority groups. The article engages particularly with the case of the US. Human capital plays a major role in economic growth and development. Furthermore, schooling is an important determinant of pay and achieved occupational status. As a major immigrant society, the US is an interesting case. Previous research has indicated that not all degrees in the US receive good returns-for example, vocational training seems to be largely discounted especially government-led programmes (Cohn \& Addison, 1998). In more recent research, Psacharopoulos and Patrinos (2004) suggest that only tertiary degrees can guarantee good returns; however, not in the case of vulnerable groups. Migrants and different minorities indeed occupy more vulnerable positions compared to majority members and broader macro events such as the economic crisis can already weaken their precarious labour market position. At the same time, some sheltering effect can be expected for those who occupy public sector jobs that should adhere strongly to anti-discrimination legislation. This article throws some light on these important ques- 
tions and concerns by focusing on three main groups of interest: white migrants, 1st and 2nd generation Black and Asians, and compares their outcomes to those of the white majority group. No finer distinction of groups is possible as this article investigates a number of important interaction effects between ethnic group and educational credentials (obtained within and outside the US) to determine the rate of return to different degrees (which is a major focus of this special issue).

\section{Literature Review}

The integration of migrants in the US economic system is a central concern of policy-makers and scholars. A faster and smoother assimilation of valuable human capital would indeed benefit the labour market, increasing its efficiency. Prior research has investigated numerous factors that may be relevant in the process, emphasizing the importance of age, gender, ethnicity, skills transferability, language barriers, and education (Akresh, 2011; Andemariam, 2007; Bratsberg \& Terrell, 2002; Chellaraj, Maskus, \& Mattoo, 2006; Dustmann \& Glitz, 2011; Enchautegui, 1998; Jasso, Massey, Rosenzweig, \& Smith, 2000; Mattoo, Neagu, \& Özden, 2012; Portes \& Rivas, 2011; White \& Glick, 2009).

High-skilled migrants represent a particularly interesting case: although the demand for them is strong in the US economy (e.g., in IT occupations; see: Bound, Demirci, Khanna, \& Turner, 2015), immigrants experience extensive disadvantage (Mattoo et al., 2012). For instance, using the New Immigrant Survey Pilot, NIS-P (Jasso et al., 2000), which follows migrants for one year after receiving green cards, Redstone Akresh (2006) reports that $50 \%$ of US legal migrants experience occupational downgrading (i.e., they have an occupational level that is lower than their last position abroad). This points to the possibility of severe underutilization of human capital which is the main concern of this paper.

To understand better the extent of underutilization of human capital, we need to be able to quantify the interplay between the country in which the education has been obtained (e.g., the sending or the host country) and the origin group of the immigrant. A degree acquired in the US is shown to have a greater impact on a migrant's economic integration than a degree acquired abroad (Redstone Akresh, 2006). This pattern appears to apply to a variety of ethnic groups. Gonzalez' (2003) study illustrates that Mexican and Latin American immigrants with US schooling perform better than their fellow countrymen, as they gain higher wages and can subsequently payoff the cost of their education entirely. Likewise, Zeng and Xie (2004) find that foreign-educated Asian immigrants earn $16 \%$ less than US born whites, US born AsianAmericans, and US educated Asian immigrants. ${ }^{1}$

A similar difference can be observed among foreign countries as well. Mattoo, Neagu and Özden (2008) report conspicuous gaps among highly educated immi- grants depending on the country of origin. Controlling for age, experience and level of education, they find that migrants educated in Latin America and Eastern Europe are more likely to suffer occupational de-skilling than migrants educated in Asia and industrial countries. This is also true for migrants' wages, as demonstrated with different datasets (e.g., the US Census and Current Population Survey) by Bratsberg and Terrell (2002) and Schoellman (2011): earnings are significantly higher for migrants educated in developed areas (e.g., Northern Europe) in comparison to migrants educated in developing ones (e.g., Central America). The variation is generally attributed to divergences in the educational quality provided (measured in terms of expenditures in tertiary education or pupil-teacher ratio) in the home countries (Bratsberg \& Terrell, 2002), or to limitations to the transferability of individuals' skills in the US (Duleep \& Regets, 1999).

In the long-run, however, differences tend to narrow down and disappear. Chiswick and Hurst (2000) suggest, indeed, that immigrants' high unemployment rates appear to have a short-term duration and stabilize after three years (or less). Also, even if a relevant portion of migrants' experience downgrading with their first US job, they quickly improve their position (Akresh, 2008). Already within the first year, average earnings increase substantially (Akresh, 2007), and employer-sponsored migrants who acquire a green card have an annual wage gain of about $\$ 11,860$ (Mukhopadhyay \& Oxborrow, 2012). Over the years, as migrants are more likely to obtain a US qualification and develop valuable social connections, experiences of economic disadvantage weakens (Akresh, 2008). In addition, Mattoo et al. (2012), pooling together data from the 1980, 1990 and 2000 US Census, show that, with time, the performance of migrants from countries with lower initial occupational placement tends to converge with the one of other better-placed at arrival migrants (Mattoo et al., 2012).

Economic assimilation tends to be strengthened and even reinforced in the second generation. Even though racial discrimination can reduce opportunities for second generation individuals in the labour market in comparison to the white majority, the second generation performs generally better than the first one (Portes \& Rivas, 2011). For instance, US born Mexican Americans have a significant earnings advantage over Mexican immigrants, as they benefit from being raised and educated directly in the US (Trejo, 2003).

More broadly, Bean, Leach and Lowell's (2004) research indicates an upward mobility of migrants over time: between 1990 and 2000 immigrants have moved from low-end jobs to middle-range positions, and occasionally to higher-range jobs.

Despite such improvements, there is also evidence that the disparities with the white majority remain substantial, and migrants never fully catch up with majoritywhite occupational levels (Portes \& Rivas, 2011). At the

\footnotetext{
${ }^{1}$ Gonzalez (2003) employs the 1980 and 1990 5\% US Census PUMS data, while Zeng and Xie (2004) uses US census data from 1990 only.
} 
same time, immigrants' employment opportunities cannot be equated to the one of ethnic minorities born within the receiving society, as Bean et al. (2004) pointed out: though both groups experience disadvantage, they do not necessarily follow the same trends. However, considering the ethnic background of migrants is crucial as this factor has major implications. For example, while Hispanics tend to be mostly manual workers with lower educational attainment, Asians are generally characterized by the possession of high human capital (Portes \& Rivas, 2011).

In this article, we acknowledge such differences and analyse the integration in the labour market of US born minorities and migrants belonging to different ethnic backgrounds (Black, Asian and Other) separately. In addition, we estimate the return to education and track how economic disadvantage develops across the 1 st and 2 nd generations, providing an overall panorama of the process. More specifically, building upon previous literature, not only we assess the gaps in the probability of employment, but we also evaluate differences between the public and private sectors, as well as the probability of being hired for high-level jobs. In this sense, we explore if the public sector effectively facilitates economic assimilation (especially regarding high quality jobs), while considering the respondent's educational level.

\section{Data and Methods}

To investigate the integration of minorities and migrants in the US labour market, we employ data from the Current Population Survey (CPS) from June 2016 (the primary source of labour force statistics in the US). The CPS gathers information for about 150,000 people and it includes questions on country of origin, parental country of origin, citizenship, and year of entry into the US, allowing meaningful analyses of sub-populations.

We focus on the following ethnic groups: White, Black, Asian, and Other (a combination of Native Americans, Pacific and Mixed). ${ }^{2}$ For each ethnicity we consider if respondents are US born, 1st- or 2nd-generation. ${ }^{3}$ Among 1st generation migrants, we further differentiate between recent (in the country for 10 years or less) and long (in the country for more than 10 years) arrivals, as they are likely to have different levels of social capital and knowledge of the job market. The sample is restricted to people of working age (16 to 64), excluding inactive individuals who are retired or disabled-giving us a sample of about 74,000 individuals.

Three main outcomes are taken into account to assess gaps in the labour market between minorities or migrants and the white majority: (1) Being employed; (2) Working in the public sector; and (3) Working in pro- fessional or managerial positions (i.e., high-level jobs). In this sense, we evaluate labour market disadvantage broadly, evaluating not only the prospects of employment, but also eventual differences between the public and private sectors and the probability of being hired for high-level jobs.

Performances in the labour market across such outcomes are estimated using binary logistic regression and shown as marginal effects at mean of covariates. All models are weighted to represent the general population, and run separately for men and women, as processes are likely to diverge because of gender. In addition, to address possible sources of bias, we apply the following covariates: age, age (squared), highest qualification obtained, urbanization, region in the US, whether they cohabit, whether a dependent child is present (see Table 1 for more details).

\section{Results}

We begin by showing the overall integration in the labour market of each group by migrant status, ethnicity and years of residence in comparison to the white majority. Models in Table 2 indicate the existence of significant negative gaps in respect to employment chances, public jobs, and high-level positions for some migrant and minority groups, even if we control for age, education, urbanization level, family status, and region. This is in line with previous research and it confirms the existence of a widespread economic disadvantage for all ethnic minorities and migrants.

For instance, as concerns natives belonging to an ethnic minority (i.e., Black, Asian, Other), it can be observed that the predicted probabilities to be employed for native Black males are 7.2 percentage points lower than native White males. The same is true for native Asian females whose likelihoods of employment are 15.2 percentage points lower than their White counterpart. Such a distinctive ethnic divide seems to be rooted in the private sector, since the second generation of both sexes (i.e., Black and Other) are actually more likely to be hired in the public sector than the white majority. This is possibly a consequence of Affirmative Action policies, which have been aimed over the last 50 years at the improvement of the employment opportunities for groups historically discriminated in the US. However, evidence indicates that this rebalancing does not reach the top of the occupational hierarchy (professional or managerial positions), which are mostly taken by the white majority-even if the minority individual has the same education level, age, family status, as that of a white majority individual.

Table 2 shows that migrants experience significant economic disadvantage. They have lower chances to get

\footnotetext{
${ }^{2}$ Notice that the CPS does not identify Hispanics as a separate race. As a matter of fact, the CPS employs the following question to identify different ethnic groups: "I am going to read you a list of five race categories. You may choose one or more races. For this survey, Hispanic origin is not a race. (Are/Is) (NAME/you) White; Black or African American; American Indian or Alaska Native; Asian; OR Native Hawaiian or Other Pacific Islander?"

${ }^{3}$ Our US born category focuses on majority members who do not have foreign parents. 2nd generation migrants are US born citizens who have foreign parents (mother or father). This means that the category "US born" does not include 2nd generation migrants, but it can include 3rd gen migrants (this meaning that their grandparents were foreigners).
} 
Table 1. Descriptive statistics by ethnicity and migrant status.

\begin{tabular}{|c|c|c|c|c|c|c|c|c|c|c|c|c|}
\hline & $\begin{array}{l}\text { White } \\
\text { US born } \\
\text { mean }\end{array}$ & $\begin{array}{l}\text { White } \\
\text { 1st gen } \\
\text { mean }\end{array}$ & $\begin{array}{l}\text { White } \\
\text { 2nd gen } \\
\text { mean }\end{array}$ & $\begin{array}{l}\text { Black } \\
\text { US born } \\
\text { mean }\end{array}$ & $\begin{array}{l}\text { Black } \\
\text { 1st gen } \\
\text { mean }\end{array}$ & $\begin{array}{l}\text { Black } \\
\text { 2nd gen } \\
\text { mean }\end{array}$ & $\begin{array}{l}\text { Other } \\
\text { US born } \\
\text { mean }\end{array}$ & $\begin{array}{l}\text { Other } \\
\text { 1st gen } \\
\text { mean }\end{array}$ & $\begin{array}{l}\text { Other } \\
\text { 2nd gen } \\
\text { mean }\end{array}$ & $\begin{array}{l}\text { Asian } \\
\text { US born } \\
\text { mean }\end{array}$ & $\begin{array}{l}\text { Asian } \\
\text { 1st gen } \\
\text { mean }\end{array}$ & $\begin{array}{l}\text { Asian } \\
\text { 2nd gen } \\
\text { mean }\end{array}$ \\
\hline Male & 0.49 & 0.50 & 0.49 & 0.45 & 0.48 & 0.48 & 0.45 & 0.46 & 0.51 & 0.47 & 0.46 & 0.53 \\
\hline Age & 40.2 & 40.9 & 33.8 & 38.1 & 40.3 & 29.1 & 35.8 & 38.4 & 29.6 & 40.7 & 40.8 & 30.4 \\
\hline Cohabiting & 0.53 & 0.63 & 0.37 & 0.28 & 0.44 & 0.17 & 0.36 & 0.54 & 0.26 & 0.46 & 0.67 & 0.29 \\
\hline \multicolumn{13}{|l|}{ Qualification } \\
\hline Secondary or Less & 0.010 & 0.17 & 0.017 & 0.0093 & 0.066 & 0.020 & 0.012 & 0.16 & 0 & 0.0051 & 0.036 & 0.0023 \\
\hline High School -No Diploma & 0.092 & 0.15 & 0.16 & 0.14 & 0.10 & 0.19 & 0.15 & 0.19 & 0.16 & 0.093 & 0.047 & 0.13 \\
\hline High School Diploma & 0.26 & 0.27 & 0.25 & 0.33 & 0.25 & 0.19 & 0.33 & 0.25 & 0.26 & 0.19 & 0.17 & 0.12 \\
\hline Some College & 0.19 & 0.12 & 0.21 & 0.22 & 0.17 & 0.26 & 0.22 & 0.16 & 0.25 & 0.18 & 0.12 & 0.19 \\
\hline Associate Degree & 0.11 & 0.056 & 0.087 & 0.092 & 0.099 & 0.077 & 0.10 & 0.068 & 0.068 & 0.096 & 0.061 & 0.078 \\
\hline Bachelor's Degree & 0.22 & 0.14 & 0.17 & 0.14 & 0.19 & 0.16 & 0.12 & 0.11 & 0.17 & 0.30 & 0.31 & 0.32 \\
\hline Master's Degree or More & 0.12 & 0.096 & 0.10 & 0.069 & 0.12 & 0.11 & 0.062 & 0.074 & 0.092 & 0.13 & 0.25 & 0.16 \\
\hline Dependent Child & 0.32 & 0.48 & 0.28 & 0.30 & 0.39 & 0.23 & 0.33 & 0.45 & 0.27 & 0.28 & 0.41 & 0.20 \\
\hline \multicolumn{13}{|l|}{ Activity } \\
\hline Employed & 0.80 & 0.75 & 0.72 & 0.71 & 0.77 & 0.62 & 0.68 & 0.71 & 0.71 & 0.75 & 0.72 & 0.67 \\
\hline Unemployed & 0.035 & 0.034 & 0.048 & 0.078 & 0.043 & 0.043 & 0.077 & 0.033 & 0.037 & 0.033 & 0.026 & 0.029 \\
\hline Inactive & 0.17 & 0.22 & 0.24 & 0.21 & 0.19 & 0.34 & 0.25 & 0.26 & 0.25 & 0.22 & 0.25 & 0.30 \\
\hline Public Sector & 0.15 & 0.065 & 0.13 & 0.18 & 0.12 & 0.13 & 0.21 & 0.065 & 0.10 & 0.23 & 0.10 & 0.12 \\
\hline Managerial or Professional Job & 0.41 & 0.24 & 0.37 & 0.28 & 0.33 & 0.41 & 0.30 & 0.22 & 0.31 & 0.47 & 0.50 & 0.57 \\
\hline \multicolumn{13}{|l|}{ Region } \\
\hline Northeast & 0.18 & 0.15 & 0.18 & 0.096 & 0.36 & 0.36 & 0.068 & 0.12 & 0.17 & 0.058 & 0.19 & 0.22 \\
\hline Midwest & 0.24 & 0.11 & 0.12 & 0.15 & 0.14 & 0.066 & 0.14 & 0.098 & 0.13 & 0.051 & 0.11 & 0.098 \\
\hline South & 0.34 & 0.36 & 0.27 & 0.67 & 0.42 & 0.42 & 0.26 & 0.25 & 0.19 & 0.11 & 0.26 & 0.18 \\
\hline West & 0.25 & 0.38 & 0.43 & 0.083 & 0.084 & 0.15 & 0.53 & 0.54 & 0.51 & 0.78 & 0.44 & 0.50 \\
\hline
\end{tabular}


Table 1. (Cont.) Descriptive statistics by ethnicity and migrant status.

\begin{tabular}{|c|c|c|c|c|c|c|c|c|c|c|c|c|}
\hline & $\begin{array}{l}\text { White } \\
\text { US born } \\
\text { mean }\end{array}$ & $\begin{array}{l}\text { White } \\
\text { 1st gen } \\
\text { mean }\end{array}$ & $\begin{array}{l}\text { White } \\
\text { 2nd gen } \\
\text { mean }\end{array}$ & $\begin{array}{l}\text { Black } \\
\text { US born } \\
\text { mean }\end{array}$ & $\begin{array}{l}\text { Black } \\
\text { 1st gen } \\
\text { mean }\end{array}$ & $\begin{array}{l}\text { Black } \\
\text { 2nd gen } \\
\text { mean }\end{array}$ & $\begin{array}{l}\text { Other } \\
\text { US born } \\
\text { mean }\end{array}$ & $\begin{array}{l}\text { Other } \\
\text { 1st gen } \\
\text { mean }\end{array}$ & $\begin{array}{l}\text { Other } \\
\text { 2nd gen } \\
\text { mean }\end{array}$ & $\begin{array}{l}\text { Asian } \\
\text { US born } \\
\text { mean }\end{array}$ & $\begin{array}{l}\text { Asian } \\
\text { 1st gen } \\
\text { mean }\end{array}$ & $\begin{array}{l}\text { Asian } \\
\text { 2nd gen } \\
\text { mean }\end{array}$ \\
\hline \multicolumn{13}{|l|}{ Urban } \\
\hline Non Metropolitan or Not Identified & 0.31 & 0.096 & 0.12 & 0.16 & 0.074 & 0.031 & 0.42 & 0.093 & 0.12 & 0.12 & 0.079 & 0.030 \\
\hline $100000-249999$ & 0.088 & 0.044 & 0.055 & 0.057 & 0.038 & 0.017 & 0.077 & 0.049 & 0.075 & 0.048 & 0.036 & 0.028 \\
\hline $250000-499999$ & 0.080 & 0.073 & 0.080 & 0.080 & 0.027 & 0.043 & 0.044 & 0.052 & 0.058 & 0.020 & 0.040 & 0.021 \\
\hline 500 000-999 999 & 0.13 & 0.11 & 0.13 & 0.12 & 0.074 & 0.040 & 0.18 & 0.16 & 0.19 & 0.40 & 0.10 & 0.13 \\
\hline $1000000-2499999$ & 0.15 & 0.14 & 0.13 & 0.20 & 0.12 & 0.11 & 0.11 & 0.22 & 0.17 & 0.066 & 0.17 & 0.16 \\
\hline $2500000-4999999$ & 0.10 & 0.15 & 0.15 & 0.080 & 0.13 & 0.19 & 0.071 & 0.19 & 0.16 & 0.11 & 0.18 & 0.21 \\
\hline over 5000000 & 0.14 & 0.39 & 0.33 & 0.30 & 0.54 & 0.57 & 0.087 & 0.25 & 0.23 & 0.24 & 0.39 & 0.41 \\
\hline \multicolumn{13}{|l|}{ Years of Residence } \\
\hline Not Foreigners & 1 & 0 & 1 & 1 & 0 & 1 & 1 & 0 & 1 & 1 & 0 & 1 \\
\hline More than 10 years & 0 & 0.76 & 0 & 0 & 0.64 & 0 & 0 & 0.73 & 0 & 0 & 0.62 & 0 \\
\hline Between $5-10$ years & 0 & 0.13 & 0 & 0 & 0.19 & 0 & 0 & 0.13 & 0 & 0 & 0.19 & 0 \\
\hline Equal or less than 4 years & 0 & 0.11 & 0 & 0 & 0.16 & 0 & 0 & 0.14 & 0 & 0 & 0.19 & 0 \\
\hline Observations & 47718 & 6543 & 4238 & 6419 & 1028 & 351 & 1921 & 367 & 294 & 396 & 2950 & 856 \\
\hline
\end{tabular}


Table 2. Ethnic and migrant gaps with white majority in labour market outcomes. Source: US Census Bureau (2016).

\begin{tabular}{|c|c|c|c|c|c|c|}
\hline & $\begin{array}{l}\text { Employed } \\
\text { (women } \\
\text { sample) }\end{array}$ & $\begin{array}{l}\text { Employed } \\
\text { (men } \\
\text { sample) }\end{array}$ & $\begin{array}{l}\text { Public Job } \\
\text { (women } \\
\text { sample) }\end{array}$ & $\begin{array}{l}\text { Public Job } \\
\text { (men } \\
\text { sample) }\end{array}$ & $\begin{array}{l}\text { Professional or } \\
\text { Managerial Job } \\
\text { (women sample) }\end{array}$ & $\begin{array}{l}\text { Professional or } \\
\text { Managerial Job } \\
\text { (men sample) }\end{array}$ \\
\hline \multicolumn{7}{|c|}{ Ref category: White US born citizens } \\
\hline White 1st gen short & $\begin{array}{l}-0.160 * * * \\
(0.021)\end{array}$ & $\begin{array}{c}0.008 \\
(0.013)\end{array}$ & $\begin{array}{c}-0.080 * * * \\
(0.012)\end{array}$ & $\begin{array}{l}-0.066 * * * \\
(0.007)\end{array}$ & $\begin{array}{l}-0.181 * * * \\
(0.028)\end{array}$ & $\begin{array}{c}-0.141 * * * \\
(0.019)\end{array}$ \\
\hline White 1st gen long & $\begin{array}{l}-0.054 * * * \\
(0.012)\end{array}$ & $\begin{array}{l}0.048^{* * *} \\
(0.007)\end{array}$ & $\begin{array}{l}-0.041 * * * \\
(0.008)\end{array}$ & $\begin{array}{c}-0.044 * * * \\
(0.006)\end{array}$ & $\begin{array}{c}-0.152^{* * *} \\
(0.016)\end{array}$ & $\begin{array}{c}-0.134 * * * \\
(0.012)\end{array}$ \\
\hline White 2nd gen & $\begin{array}{c}-0.001 \\
(0.011)\end{array}$ & $\begin{array}{c}-0.014+ \\
(0.008)\end{array}$ & $\begin{array}{c}0.007 \\
(0.010)\end{array}$ & $\begin{array}{c}0.006 \\
(0.008)\end{array}$ & $\begin{array}{c}-0.023 \\
(0.018)\end{array}$ & $\begin{array}{c}-0.030+ \\
(0.016)\end{array}$ \\
\hline Black US born & $\begin{array}{c}-0.018+ \\
(0.010)\end{array}$ & $\begin{array}{l}-0.072 * * * \\
(0.009)\end{array}$ & $\begin{array}{l}0.065^{* * *} \\
(0.010)\end{array}$ & $\begin{array}{l}0.044^{* * *} \\
(0.009)\end{array}$ & $\begin{array}{c}-0.070 * * * \\
(0.013)\end{array}$ & $\begin{array}{c}-0.116 * * * \\
(0.012)\end{array}$ \\
\hline Black 1st gen short & $\begin{array}{l}-0.140 * * * \\
(0.042)\end{array}$ & $\begin{array}{c}-0.067^{*} \\
(0.034)\end{array}$ & $\begin{array}{c}-0.049+ \\
(0.029)\end{array}$ & $\begin{array}{l}-0.022 \\
(0.024)\end{array}$ & $\begin{array}{c}-0.179 * * * \\
(0.052)\end{array}$ & $\begin{array}{l}-0.141^{* * *} \\
(0.041)\end{array}$ \\
\hline Black 1st gen long & $\begin{array}{c}0.042+ \\
(0.025)\end{array}$ & $\begin{array}{c}0.018 \\
(0.020)\end{array}$ & $\begin{array}{c}0.024 \\
(0.026)\end{array}$ & $\begin{array}{c}0.028 \\
(0.021)\end{array}$ & $\begin{array}{c}-0.037 \\
(0.038)\end{array}$ & $\begin{array}{c}-0.124 * * * \\
(0.027)\end{array}$ \\
\hline Black 2nd gen & $\begin{array}{c}-0.075^{*} \\
(0.038)\end{array}$ & $\begin{array}{c}-0.067^{*} \\
(0.028)\end{array}$ & $\begin{array}{c}0.031 \\
(0.039)\end{array}$ & $\begin{array}{c}0.005 \\
(0.032)\end{array}$ & $\begin{array}{c}-0.045 \\
(0.053)\end{array}$ & $\begin{array}{c}-0.025 \\
(0.054)\end{array}$ \\
\hline Other US born & $\begin{array}{c}-0.024 \\
(0.018)\end{array}$ & $\begin{array}{c}-0.039 * \\
(0.015)\end{array}$ & $\begin{array}{c}0.045^{* *} \\
(0.017)\end{array}$ & $\begin{array}{c}0.053^{* *} \\
(0.016)\end{array}$ & $\begin{array}{c}-0.037 \\
(0.029)\end{array}$ & $\begin{array}{c}-0.050^{*} \\
(0.025)\end{array}$ \\
\hline Other 1st gen short & $\begin{array}{c}-0.170 * \\
(0.078)\end{array}$ & $\begin{array}{c}0.059 * \\
(0.030)\end{array}$ & $\begin{array}{l}-0.104 * * * \\
(0.025)\end{array}$ & & $\begin{array}{l}-0.278^{* * *} \\
(0.084)\end{array}$ & $\begin{array}{c}-0.270 * * * \\
(0.036)\end{array}$ \\
\hline Other 1st gen long & $\begin{array}{c}-0.025 \\
(0.042)\end{array}$ & $\begin{array}{c}0.048+ \\
(0.028)\end{array}$ & $\begin{array}{c}-0.069 * * \\
(0.027)\end{array}$ & $\begin{array}{c}-0.032 \\
(0.025)\end{array}$ & $\begin{array}{c}-0.029 \\
(0.070)\end{array}$ & $\begin{array}{c}-0.156^{* * *} \\
(0.046)\end{array}$ \\
\hline Other 2nd gen & $\begin{array}{c}-0.011 \\
(0.045)\end{array}$ & $\begin{array}{c}0.015 \\
(0.024)\end{array}$ & $\begin{array}{c}0.010 \\
(0.041)\end{array}$ & $\begin{array}{c}-0.006 \\
(0.032)\end{array}$ & $\begin{array}{c}-0.193^{* *} \\
(0.061)\end{array}$ & $\begin{array}{c}0.030 \\
(0.061)\end{array}$ \\
\hline Asian US born & $\begin{array}{l}-0.152^{* * *} \\
(0.045)\end{array}$ & $\begin{array}{c}-0.027 \\
(0.037)\end{array}$ & $\begin{array}{c}0.011 \\
(0.034)\end{array}$ & $\begin{array}{c}0.054 \\
(0.039)\end{array}$ & $\begin{array}{c}-0.028 \\
(0.059)\end{array}$ & $\begin{array}{c}-0.051 \\
(0.054)\end{array}$ \\
\hline Asian 1st gen short & $\begin{array}{l}-0.298^{* * *} \\
(0.025)\end{array}$ & $\begin{array}{c}-0.132 * * * \\
(0.024)\end{array}$ & $\begin{array}{l}-0.075^{* * *} \\
(0.013)\end{array}$ & $\begin{array}{l}-0.053^{* * *} \\
(0.010)\end{array}$ & $\begin{array}{c}-0.100 * * \\
(0.035)\end{array}$ & $\begin{array}{c}0.073^{*} \\
(0.030)\end{array}$ \\
\hline Asian 1st gen long & $\begin{array}{l}-0.066^{* * *} \\
(0.018)\end{array}$ & $\begin{array}{c}-0.006 \\
(0.015)\end{array}$ & $\begin{array}{l}-0.057^{* * *} \\
(0.009)\end{array}$ & $\begin{array}{l}-0.032^{* * *} \\
(0.009)\end{array}$ & $\begin{array}{c}-0.116^{* * *} \\
(0.022)\end{array}$ & $\begin{array}{c}-0.064^{* * *} \\
(0.019)\end{array}$ \\
\hline Asian 2nd gen & $\begin{array}{l}-0.105^{* * *} \\
(0.028)\end{array}$ & $\begin{array}{c}-0.064^{* * *} \\
(0.019)\end{array}$ & $\begin{array}{c}-0.060 * * * \\
(0.016)\end{array}$ & $\begin{array}{c}-0.038^{* *} \\
(0.013)\end{array}$ & $\begin{array}{c}0.061 \\
(0.040)\end{array}$ & $\begin{array}{c}0.093^{*} \\
(0.038)\end{array}$ \\
\hline Observations & 37464 & 35617 & 28220 & 30824 & 28242 & 30876 \\
\hline
\end{tabular}

Notes: Standard errors in parentheses; estimated gap by ethnicity (White; Black; Other; Asian) and migrant status (short $\leq 10 y$; long $>10 y$; 2nd gen) for 16-64, excluding retired or inactive people with disability; weighted; robust SE; controlling for age, age (squared), education, urbanization, cohabiting, dependent child, f.e. for region; $+p<0.1 * p<0.05 * * p<0.01 * * * p<0.001$. Reference category: White US born citizens.

a job, be employed in the public sector, or be hired in high-level jobs. This tends to be true across all ethnicities, and it is particularly strong for recent arrivals (as also suggested in Chiswick \& Hurst, 2000). Indeed, difficulties in the economic integration of migrants arise primarily at the beginning of the integration process (especially for women), when they are likely to have a worse positioning in the job market and fewer connections. The gap with the white majority, nevertheless, seems to fade away over time: negative coefficients are large and very significant for migrants who stayed in the country for less than 10 years, but they decrease in size and relevance for migrants with longer duration of stay.
However, relevant gaps remain in respect to public and high-level jobs, indicating that the evolution of migrants' social capital, market knowledge, and US schooling in the 2 nd generation is not sufficient to reverse the trend entirely.

There are some noticeable exceptions to the patterns described above. In the first place, it can be noticed that among men arrived in the US, White 1st generation who stayed for more than 10 years and Other migrants are more likely to get a job, though they tend not to have a position in the public sector or be hired as a manager or a professional. In this sense, the US job market appears to be open towards migrants willing to get 
lower level jobs in the private sector, as these positions are possibly disregarded by White US born citizens. Indeed, such occupations are more likely to be taken by migrants with low educational levels-more than $30 \%$ of White and Other men migrants have (at most) attended High school without obtaining a diploma.

Secondly, contrary to other ethnicities, Asian migrants' experiences of economic disadvantage persist over time, remaining significant both for the 1st and the 2 nd generation. On the other hand, Asians are the only migrant group to show a positive coefficient for highlevel jobs. As a matter of fact, the likelihood of having a managerial or professional position for recent migrants and 2nd generation Asian men are 7.3 and 9.3 (respectively) percentage points higher than for White US born.
Plausibly, as Asians tend to have a higher educational level in comparison to other migrants and US born citizens, ${ }^{4}$ they might prefer to stay for a longer period in the job market in the attempt of obtaining higher level jobs (Portes \& Rivas, 2011).

Moving to the benefits of education, in line with previous studies, Table 3 displays the returns to education by ethnicity and migrant status. Overall, results indicate that having a post-secondary qualification strongly increases the chances of both the second generation and migrants to be employed and get better positions. The effect tends to be more significant for women, who, as it already emerged in Table 2, experience worse labour opportunities than their male counterpart. The chances to obtain a high-level job are particularly strengthened,

Table 3. Returns to high education by ethnicity and migrant status. Source: US Census Bureau (2016).

\begin{tabular}{|c|c|c|c|c|c|c|}
\hline & $\begin{array}{l}\text { Employed } \\
\text { (women } \\
\text { sample) }\end{array}$ & $\begin{array}{l}\text { Employed } \\
\text { (men } \\
\text { sample) }\end{array}$ & $\begin{array}{l}\text { Public Job } \\
\text { (women } \\
\text { sample) }\end{array}$ & $\begin{array}{l}\text { Public Job } \\
\text { (men } \\
\text { sample) }\end{array}$ & $\begin{array}{l}\text { Professional or } \\
\text { Managerial Job } \\
\text { (women sample) }\end{array}$ & $\begin{array}{l}\text { Professional or } \\
\text { Managerial Job } \\
\text { (men sample) }\end{array}$ \\
\hline \multicolumn{7}{|c|}{ (Ref categories: at most High school by ethnicity and migrant status) } \\
\hline $\begin{array}{l}\text { White US born with } \\
\text { higher education }\end{array}$ & $\begin{array}{l}0.141 * * * \\
(0.007)\end{array}$ & $\begin{array}{l}0.053^{* * *} \\
(0.005)\end{array}$ & $\begin{array}{l}0.084^{* * *} \\
(0.006)\end{array}$ & $\begin{array}{l}0.070 * * * \\
(0.005)\end{array}$ & $\begin{array}{l}0.376^{* * *} \\
(0.008)\end{array}$ & $\begin{array}{l}0.362^{* * *} \\
(0.007)\end{array}$ \\
\hline $\begin{array}{l}\text { White 1st gen with } \\
\text { higher education }\end{array}$ & $\begin{array}{l}0.180^{* * *} \\
(0.019)\end{array}$ & $\begin{array}{c}-0.037 * * \\
(0.013)\end{array}$ & $\begin{array}{l}0.072 * * * \\
(0.012)\end{array}$ & $\begin{array}{l}0.060^{* * *} \\
(0.009)\end{array}$ & $\begin{array}{l}0.365^{* * *} \\
(0.018)\end{array}$ & $\begin{array}{l}0.336^{* * *} \\
(0.016)\end{array}$ \\
\hline $\begin{array}{l}\text { White } 2 \text { nd gen with } \\
\text { higher education }\end{array}$ & $\begin{array}{l}0.168^{* * *} \\
(0.021)\end{array}$ & $\begin{array}{l}0.053^{* * *} \\
(0.015)\end{array}$ & $\begin{array}{l}0.084^{* * *} \\
(0.020)\end{array}$ & $\begin{array}{l}0.102 * * * \\
(0.016)\end{array}$ & $\begin{array}{l}0.327^{* * *} \\
(0.026)\end{array}$ & $\begin{array}{l}0.331^{* * *} \\
(0.023)\end{array}$ \\
\hline $\begin{array}{l}\text { Black US born with } \\
\text { higher education }\end{array}$ & $\begin{array}{l}0.183^{* * *} \\
(0.018)\end{array}$ & $\begin{array}{l}0.096 * * * \\
(0.017)\end{array}$ & $\begin{array}{l}0.126 * * * \\
(0.016)\end{array}$ & $\begin{array}{l}0.105^{* * *} \\
(0.016)\end{array}$ & $\begin{array}{l}0.347^{* * *} \\
(0.018)\end{array}$ & $\begin{array}{l}0.264 * * * \\
(0.018)\end{array}$ \\
\hline $\begin{array}{l}\text { Black 1st gen with } \\
\text { higher education }\end{array}$ & $\begin{array}{l}0.171 * * * \\
(0.046)\end{array}$ & $\begin{array}{c}0.051 \\
(0.037)\end{array}$ & $\begin{array}{l}0.101^{* *} \\
(0.035)\end{array}$ & $\begin{array}{l}0.129 * * * \\
(0.030)\end{array}$ & $\begin{array}{l}0.371 * * * \\
(0.042)\end{array}$ & $\begin{array}{l}0.368 * * * \\
(0.037)\end{array}$ \\
\hline $\begin{array}{l}\text { Black } 2 \text { nd gen with } \\
\text { higher education }\end{array}$ & $\begin{array}{l}0.237^{* *} \\
(0.083)\end{array}$ & $\begin{array}{l}0.190 * * \\
(0.067)\end{array}$ & $\begin{array}{c}0.085 \\
(0.090)\end{array}$ & $\begin{array}{l}0.121 * \\
(0.051)\end{array}$ & $\begin{array}{l}0.367^{* * *} \\
(0.095)\end{array}$ & $\begin{array}{l}0.284 * * \\
(0.097)\end{array}$ \\
\hline $\begin{array}{l}\text { Other US born with } \\
\text { higher education }\end{array}$ & $\begin{array}{l}0.122^{* * *} \\
(0.037)\end{array}$ & $\begin{array}{l}0.141^{* * *} \\
(0.031)\end{array}$ & $\begin{array}{c}0.040 \\
(0.035)\end{array}$ & $\begin{array}{c}0.060+ \\
(0.031)\end{array}$ & $\begin{array}{l}0.235^{* * *} \\
(0.048)\end{array}$ & $\begin{array}{l}0.262 * * * \\
(0.040)\end{array}$ \\
\hline $\begin{array}{l}\text { Other 1st gen with } \\
\text { higher education }\end{array}$ & $\begin{array}{l}0.235^{* *} \\
(0.079)\end{array}$ & $\begin{array}{c}0.019 \\
(0.048)\end{array}$ & $\begin{array}{c}0.073^{*} \\
(0.036)\end{array}$ & $\begin{array}{c}0.016 \\
(0.040)\end{array}$ & $\begin{array}{l}0.362^{* * *} \\
(0.079)\end{array}$ & $\begin{array}{l}0.275^{* * *} \\
(0.068)\end{array}$ \\
\hline $\begin{array}{l}\text { Other } 2 \text { nd gen with } \\
\text { higher education }\end{array}$ & $\begin{array}{c}0.032 \\
(0.082)\end{array}$ & $\begin{array}{c}0.011 \\
(0.046)\end{array}$ & $\begin{array}{c}0.154+ \\
(0.084)\end{array}$ & & $\begin{array}{l}0.354^{* * *} \\
(0.098)\end{array}$ & $\begin{array}{l}0.418^{* * *} \\
(0.094)\end{array}$ \\
\hline $\begin{array}{l}\text { Asian US born with } \\
\text { higher education }\end{array}$ & $\begin{array}{c}0.235^{*} \\
(0.111)\end{array}$ & $\begin{array}{c}0.211^{*} \\
(0.091)\end{array}$ & $\begin{array}{c}0.110 \\
(0.072)\end{array}$ & $\begin{array}{c}0.068 \\
(0.077)\end{array}$ & $\begin{array}{l}0.462^{* * *} \\
(0.108)\end{array}$ & $\begin{array}{l}0.376 * * * \\
(0.080)\end{array}$ \\
\hline $\begin{array}{l}\text { Asian 1st gen with } \\
\text { higher education }\end{array}$ & $\begin{array}{c}0.026 \\
(0.031)\end{array}$ & $\begin{array}{c}0.020 \\
(0.027)\end{array}$ & $\begin{array}{l}0.070 * * * \\
(0.017)\end{array}$ & $\begin{array}{l}0.052^{* *} \\
(0.017)\end{array}$ & $\begin{array}{l}0.465^{* * *} \\
(0.027)\end{array}$ & $\begin{array}{l}0.535^{* * *} \\
(0.024)\end{array}$ \\
\hline $\begin{array}{l}\text { Asian } 2 \text { nd gen with } \\
\text { higher education }\end{array}$ & $\begin{array}{l}0.269 * * * \\
(0.065)\end{array}$ & $\begin{array}{c}0.095^{*} \\
(0.044)\end{array}$ & $\begin{array}{c}0.059 \\
(0.047)\end{array}$ & $\begin{array}{l}0.093^{* * *} \\
(0.021)\end{array}$ & $\begin{array}{l}0.472^{* * *} \\
(0.084)\end{array}$ & $\begin{array}{l}0.424^{* * *} \\
(0.074)\end{array}$ \\
\hline Observations & 37464 & 35617 & 28220 & 30809 & 28242 & 30876 \\
\hline
\end{tabular}

Notes: Standard errors in parentheses; estimated returns to education (Higher Education; compared to at most High School) by ethnicity (White; Black; Other; Asian) and migrant status (1st gen; 2nd gen) for 16-64, excluding retired or inactive people with disability; weighted; robust SE; controlling for age, age (squared), urbanization, cohabiting, dependent child, f.e. for region $+p<0.1 * p<0.05 * *$ $\mathrm{p}<0.01 * * * \mathrm{p}<0.001$. Reference categories: "at most High School" by ethnic group and migrant status (e.g., White 1st gen migrants with higher education are compared to White 1st gen migrants with a High school degree at most).

\footnotetext{
${ }^{4}$ On average, $56 \%$ of 1 st generation Asian migrants and $48 \%$ of 2 nd generation Asians have a Bachelor's qualification or higher, while only $34 \%$ of White US born have the same educational level.
} 
as higher qualifications are required for such positions. For instance, a 1st generation Black woman with a higher education has 37.1 percentage points higher predicted probability to obtain a managerial occupation compared to a 1st generation Black woman with at most high school diploma. The same pattern is valid for men and all other minorities.
Having a post-secondary qualification is also positively correlated with being employed in the public sector, suggesting a widespread application of more meritocratic and transparent hiring criteria in the public sector. To understand if this applies only to specific occupations, Table 4 further explores differences in the job market by focusing on high-level positions. More specifically,

Table 4. Ethnic and migrant gaps in private and public sectors for professional or managerial jobs. Source: US Census Bureau (2016).

Professional or Managerial Job

Professional or Managerial Job

(women sample) (men sample)

Ref categories: White US born in the private and public sectors

White 1st gen

Private

$-0.152 * * *$

(0.015)

$-0.147^{* * *}$

Public

$-0.124 * *$

(0.011)

(0.048)

$-0.044$

(0.053)

White 2nd gen

Private

$-0.030$

$-0.035^{*}$

(0.019)

(0.017)

Public

$-0.010$

$-0.001$

(0.044)

(0.046)

\section{Black US born}

Private

Public

(0.015)

(0.013)

$-0.129 * * *$

$-0.035$

(0.030)

(0.032)

Black 1st gen

Private

$-0.086^{*}$

$-0.136 * * *$

(0.034)

(0.025)

Public

$-0.040$

$-0.088$

(0.080)

(0.066)

Black 2nd gen

Private

$-0.064$

$-0.047$

(0.055)

(0.056)

Public

$-0.034$

$-0.160$

(0.141)

(0.221)

\section{Other US born}

Private

$-0.041$

$-0.048+$

(0.032)

(0.029)

Public

$-0.055$

$-0.056$

(0.070)

(0.055)

Other 1st gen

Private

$-0.087$

(0.062)

$-0.184^{* * *}$

$-0.045$

(0.038)

Public

(0.312)

$-0.064$

(0.205)

Other 2nd gen

Private

$-0.160 *$

$-0.023$

(0.069)

(0.064)

Public

$-0.372 * * *$

$-0.566^{* * *}$

(0.100)

(0.083) 
Table 4. (Cont.) Ethnic and migrant gaps in private and public sectors for professional or managerial jobs. Source: US Census Bureau (2016).

$\begin{array}{ll}\begin{array}{l}\text { Professional or Managerial Job } \\ \text { (women sample) }\end{array} & \text { Professional or Managerial Job } \\ \text { (men sample) }\end{array}$

\begin{tabular}{lcc}
\hline Ref categories: White US born in the private and public sectors & \\
\hline Asian US born & & $-0.094^{*}$ \\
Private & -0.030 & $(0.048)$ \\
& $(0.069)$ & 0.190 \\
Public & -0.057 & $(0.199)$ \\
& $(0.102)$ & \\
\hline Asian 1st gen & & -0.027 \\
Private & $-0.093^{* * *}$ & $(0.018)$ \\
& $(0.020)$ & -0.011 \\
Public & $-0.169^{* *}$ & $(0.050)$ \\
& $(0.057)$ & \\
Asian 2nd gen & & $0.100^{*}$ \\
Private & $0.106^{* *}$ & $(0.039)$ \\
Public & $(0.041)$ & -0.005 \\
& $-0.287^{* *}$ & $(0.105)$ \\
\hline Observations & $(0.103)$ & 30856 \\
\hline
\end{tabular}

Notes: Standard errors in parentheses; estimated gap by ethnicity (White; Black; Other; Asian) and migrant status (short $\leq 10 y ;$ long $>10 y$; 2nd gen) for 16-64, excluding retired or inactive people with disability; weighted; robust SE; controlling for age, age (squared), education, urbanization, cohabiting, dependent child, f.e. for region; $+p<0.1 * p<0.05 * * p<0.01 * * * p<0.001$. Reference category: White US born citizens in the private and public sectors (e.g., Black 1st gen migrants working in the private sector are compared to White US born citizens working in the private sector).

it shows the likelihood of each migrant group and ethnicity to get a professional or managerial position in the private and public sectors in comparison to the white majority (controlling for age, education, urbanization level, family status, and region).

Results indicate a strong closure of the private sector with little access of minorities and migrants to high-level positions. This pattern appears to be very consistent and significant across the different groups (with a single exception of 2 nd generation Asians). However, evidence is more mixed for professional and managerial positions in the public sector, where the estimated gaps with the White majority are often insignificant. Even though in several instances we can observe a clear economic disadvantage (e.g., Black female US born, or 2 nd generation Asian females), the trend appears to be rather erratic, showing even positive coefficients (the group of 2 nd generation Other males is the only one for which this result is significant). Our findings suggest that equity exists in the public sector that extends also to higher level positions, which could potentially lead to more beneficial outcomes in the future.

\section{Conclusions}

Our results indicate strong and important gains to ethnic minorities employed in the public sector and for those with tertiary degrees. Having a post-secondary qualification increases the chances of both the second generation and migrants to be employed and obtain better positions. The effect tends to be stronger and carries important implications for women, who, as our models suggest experience worse labour opportunities than their male counterpart. The advantage for a degree holder is then likely to translate to better occupational attainment. Occupational attainment gains remain associated with public sector employment, underlying its importance in the fight against inequality and the existence of racial and ethnic hierarchies. Yet, difficulties in the economic integration of migrants exist which are more intense at the beginning (especially for women), when migrants are less likely to have a sure footing in the job market of the host society and lack the connections that can ensure good employment prospects.

\section{Acknowledgments}

This research and this thematic issue have been supported by funding from the European Commission (Grant number H2020 649255).

\section{Conflict of Interests}

The authors declare no conflict of interests. 


\section{References}

Akresh, I. R. (2007). US immigrants' labor market adjustment: Additional human capital investment and earnings growth. Demography, 44(4), 865-881.

Akresh, I. R. (2008). Occupational trajectories of legal US immigrants: Downgrading and recovery. Population and Development Review, 34(3), 435-456.

Akresh, I. R. (2011). Wealth accumulation among US immigrants: A study of assimilation and differentials. Social Science Research, 40(5), 1390-1401.

Andemariam, E. M. (2007). The challenges and opportunities faced by skilled African immigrants in the US job market: A personal perspective. Journal of Immigrant \& Refugee Studies, 5(1), 111-116.

Bean, F. D., Leach, M., \& Lowell, B. L. (2004). Immigrant job quality and mobility in the United States. Work and Occupations, 31(4), 499-518.

Bound, J., Demirci, M., Khanna, G., \& Turner, S. (2015). Finishing degrees and finding jobs: US higher education and the flow of foreign IT workers. Innovation Policy and the Economy, 15(1), 27-72.

Bratsberg, B., \& Terrell, D. (2002). School quality and returns to education of US immigrants. Economic Inquiry, 40(2), 177-198.

Chellaraj, G., Maskus, K. E., \& Mattoo, A. (2006). Skilled immigrants, higher education, and US innovation. In Ç, Özden \& M. Schiff (Eds.), International migration, remittances and the brain drain (245-259). Washington, D.C.: World Bank Group.

Chiswick, B. R., \& Hurst, M. E. (2000). The employment, unemployment and unemployment compensation benefits of immigrants (IZA Discussion Paper 129). Bonn: IZA Institute of Labor Economics.

Cohn, E., \& Addison, J. T. (1998). The economic returns to lifelong learning in OECD countries. Education Economics, 6(3), 253-307.

Duleep, H. O., \& Regets, M. C. (1999). Immigrants and human-capital investment. American Economic Review, 89(2), 186-191.

Dustmann, C., \& Glitz, A. (2011). Migration and education. In E. A. Hanushek, S. Machin, \& L. Woessmann (Eds.), Handbook of the economics of education (vol. 4, pp. 327-439). Elsevier.
Enchautegui, M. E. (1998). Low-skilled immigrants and the changing American labor market. Population and development review, 811-824.

Gonzalez, A. (2003). The education and wages of immigrant children: The impact of age at arrival. Economics of Education Review, 22(2), 203-212.

Jasso, G., Massey, D. S., Rosenzweig, M. R., \& Smith, J. P. (2000). The New Immigrant Survey Pilot (NIS-P): Overview and new findings about US legal immigrants at admission. Demography, 37(1), 127-138.

Mattoo, A., Neagu, I. C., \& Özden, Ç. (2008). Brain waste? Educated immigrants in the US labor market. Journal of Development Economics, 87(2), 255-269.

Mattoo, A., Neagu, I. C., \& Özden, Ç. (2012). Performance of skilled migrants in the US: A dynamic approach. Regional Science and Urban Economics, 42(5), 829-843.

Mukhopadhyay, S., \& Oxborrow, D. (2012). The value of an employment-based green card. Demography, 49(1), 219-237.

Portes, A., \& Rivas, A. (2011). The adaptation of migrant children. The future of children, 21(1), 219-246.

Psacharopoulos, G., \& Patrinos, H. A. (2004). Returns to investment in education: A further update. Education Economics, 12(2), 111-134.

Redstone Akresh, I. (2006). Occupational mobility among legal immigrants to the United States. International Migration Review, 40(4), 854-884.

Schoellman, T. (2011). Education quality and development accounting. The Review of Economic Studies, 79(1), 388-417.

Trejo, S. J. (2003). Intergenerational progress of Mexicanorigin workers in the US labor market. Journal of Human Resources, 38(3), 467-489.

US Census Bureau. (2016). The current population survey (CPS). United States Census Bureau. Retrieved from www.census.gov/programs-surveys/cps.html

White, M. J., \& Glick, J. E. (2009). Achieving anew: How new immigrants do in American schools, jobs, and neighborhoods. New York, NY: Russell Sage Foundation.

Zeng, Z., \& Xie, Y. (2004). Asian-Americans' earnings disadvantage reexamined: The role of place of education. American Journal of Sociology, 109(5), 1075-1108.

\section{About the Authors}

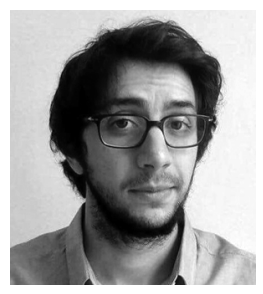

Sergio Lo lacono is a Max Weber Fellow at the European University Institute (EUI) in Florence, Italy. He received his PhD in Sociology at the University of Essex under the ESRC +3 Advanced Quantitative Methods scheme, and holds a master's degree in Political Science from the University of Toronto. His main research interests concern trust, diversity, social cohesion, collective action dilemmas and social networks. 


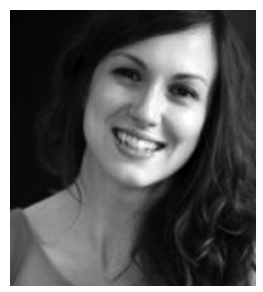

Neli Demireva (PhD) is a Senior Lecturer in Sociology at the University of Essex. Her research interests include migration, inter-ethnic ties, social cohesion, ethnic penalties and multiculturalism. She currently holds a BA grant on "Understanding the Ecology of Disadvantage: Betting Agents, Crime and the British Neighbourhood". From September 2015, she started working on the project "GEMM: Growth, Equal Opportunities, Migration and Markets" as part of the Horizon 2020 programme of the European Commission "EURO-2-2014: The European growth agenda Research and Innovation action 4: Migration, prosperity and growth". This project addresses the challenges and barriers that European countries face in managing the mobility of persons to realize competitiveness and growth. 